\title{
Antiviral Activity of Substituted Chalcones and their Respective Cu(ii), Ni(ii) and Zn(ii) Complexes.
}

\author{
K.G.MALLIKARJUN \\ Department of Chemistry, Jawahar Navodaya Vidyalaya \\ PEDDAPURAM - 533 437, East Godavari, (A.P.) India.
}

Received 13 October 2004; Accepted 14 December 2004

\begin{abstract}
Complexes of $\mathrm{Cu}(\mathrm{II}), \mathrm{Ni}(\mathrm{II})$ and $\mathrm{Zn}$ (II) with of 3-(phenyl)-1-(2'hydroxynaphthyl) - 2 - propen - 1 - one (PHPO) , 3 - (4-chlorophenyl) - 1- (2'hydroxynaphthyl)-2-propen - 1 - one (CPHPO), 3 - (4 -methoxyphenyl) -1-(2'hydroxynapthyl)-2-propen-1-one(MPHPO),3 - (3,4-dimethoxyphenyl) -1-(2'hydroxynaphthyl) - 2 - propen - 1 - one (DMPHPO) have been prepared and the purity of the samples were checked by elemental analysis. The ligands and their $\mathrm{Cu}$ (II), $\mathrm{Ni}$ (II) and $\mathrm{Zn}$ (II) complexes were tested on the infectivity of tobacco ring spot virus(TRSV) using cowpea (Vigna Sinensis) as a local lesions assay host. All the compounds were tested at different concentrations $(250 \mathrm{ppm}$ to $1500 \mathrm{ppm})$ on the infectivity of the virus by applying them either with virus inoculum or 24 hours before of after virus inoculation to the test plants. The compounds were found to have varied effects on virus infectivity depending on compounds concentration and method of application. The statistical significance of the data was determined by using analysis of variance.
\end{abstract}

Key words: Metal Complexes, Chalcones, Antiviral Activity, Cowpea(Vigna Sinensis) and Tobacco ring spot virus (TRSV)

\section{Introduction}

Anjaneyulu et al $^{1}$ have suggested mechanism for the toxic action exhibites by metal chelates on the growth of the microorganism. The high toxic nature of the metal compleses towards virus can be explained on the basis of the chelates therapy. Structural studies on several metal chelates of $\beta$ diketones and 2-hydroxycarbonyl compounds have been reviewed by Holm and O'Connor ${ }^{2}$. Lense etal $^{3}$ reported that o-hydroxychalcones are much more reactive with metal ions than the ketones and aldehyders from which then are synthesized.Among the various o-hydroxychalcones, o-hydroxycarbonyl compounds form a distinct category which can form chelates with metal ions with low spin square-planar configuration, which do not easily form adducts and this has been attributed to the presence of extensive conjugation. Extensive conjugation was found to be responsible for the strong field nature of the ligand ${ }^{4}$. Chalcones were found to be physiologically and pharmacologically active. They were also found to have germicidal ${ }^{5}$, bactericidal ${ }^{6}$, fungicidal ${ }^{7}$ and carcinogenic activities ${ }^{8}$. Several of the chalcones have been employed as useful analytical reagent. 
In the present study I have investigated the effect of $\mathrm{Cu}(\mathrm{II}), \mathrm{Ni}(\mathrm{II})$ and $\mathrm{Zn}(\mathrm{II})$ complexes of 3(phenyl)-1-(2'-hydroxynaphthyl) - 2 - propen - 1 - one (PHPO) , 3 - (4-chlorophenyl) - 1- (2'hydroxynaphthyl)-2-propen - 1 - one (CPHPO), 3 - (4 -methoxyphenyl) -1-(2'-hydroxynapthyl)-2propen-1-one(MPHPO),3 - (3,4-dimethoxyphenyl) -1-(2'-hydroxynaphthyl) - 2 - propen - 1 - one (DMPHPO) on the growth of virus (vigna sinensis) on cowpea plants.

\section{Experimental}

The chalcones were prepared by the condensation of 2-hydroxy-1-acetonaphthone. With benzaldehyde, chlorobenzaldehyde, methoxybenzaldehyde and dimethoxybenzaldehyde employing the Claisen-Schmidt condensation reported earlier? ${ }^{9}$ The $\mathrm{Cu}(\mathrm{II}), \mathrm{Ni}(\mathrm{II})$ and $\mathrm{Zn}(\mathrm{II})$ complexes were prepared according to the procedure described in our earlier communication ${ }^{10,11,12}$

The virus inoculum was prepared by grinding $6 \mathrm{TRSV}$ local lesions from cowpea/ml of cold $0.01 \mathrm{M}$ potassium phosphate buffer ( $\mathrm{pH} 7.0)$ in a mortor. The extract was passed through two folds of muslin cloth and then used as virus inoculum.

Solutions of $\mathrm{Cu}(\mathrm{II}), \mathrm{Ni}(\mathrm{II})$ and Zinc(II) complexes of PHPO, CPHPO, MPHPO and DMPHPO were prepared by dissolving the complex in dioxane $(0.1 \mathrm{M})$. Lower concentrations $(1500,1250$, $1000,750,500$ and $250 \mathrm{ppm}$ )were prepared by proportionate dilution with dioxane. Blank solution was prepared by using $2 \mathrm{ml}$ of dioxane $+2 \mathrm{ml}$ of inoculum buffer $+1 \mathrm{ml}$ of sterilized distilled water.

Procedure

$2 \mathrm{ml}$ of the complex solution, $2 \mathrm{ml}$ of inoculum buffer and $1 \mathrm{ml}$ of sterilized distilled water were transferred into a sterilized test tube $(20 \mathrm{ml})$. The resulting solution was thoroughly mixed by shaking for about ten minutes at room temperature and then transferred into a petri dish. The test plants (equal size leaves) dusted with carborundum power (600 mesh) were inoculated with the solution by using muslin cloth pads. The control sets were similarly treated with the blank solution.

The above procedure was repeated with different concentrations of the complex solution. In each experiment five plants (six equal size leaves have been selected from each plant) were subjected to the above mentioned treatment and each procedure was repeated thrice.

All the experiments were performed in the insect free glass house. The number of local lesions were counted 4 - days after inoculation. The percentage inhibition was calculated by the relation.

Percentage of inhibition $=[(\mathrm{C}-\mathrm{T}) / \mathrm{C}] \times 100$

Where $\mathrm{C}=$ Control lesions, $\mathrm{T}=$ Tested plant lesions.

\section{Results and Discussion}

All the complexes have shown inhibition of viral growth on cowpea plant leaves indicating that they are more toxic to virus than the respective ligands (Table. 1 ). The high toxic nature of the metal complexes towards virus can be explained on the basis of the chelate therpy ${ }^{13}$. Lipids and polysaccharides are important constituents of cell wall and cell membrane and these seem to be preferred sites for heavy metal ion interaction. These contain ligands having amino, phosphate, carbonyl and cystinyl groups which not only maintain the integrity of the membranes by acting as diffusion barriers but also produce suitable sites for bonding. Chelation reduces the polarity of the metal ion in the complex mainly due to the partial sharing of its positive charges with the donor groups and possible $\pi$ - electron delocalization over the whole chelating ring system through $\mathrm{p} \pi-\mathrm{p} \pi$ and $\mathrm{d} \pi$ $-\mathrm{d} \pi$ interaction of the orbitals of ligands and metal ions and increases the liphophilic character and favours interactions of metals with lipids, this probably leads to the break down of the permeability barrier of the cells resulting ${ }^{14}$ in interference with the normal cell process.

Earlier investigation ${ }^{1}$ have suggested two types of mechanisms for the toxic action exhibited by metal chelates on the growth of the microorganism.

a. Thiols which are the vital constituents in the living cells, having reduction potential for the disulphide form at or below $200 \mathrm{mv}$ may be oxidized easily by metal complexes as per the redox reaction.

$$
2 \mathrm{RSH}+\mathrm{ML}_{2} \leftrightarrow \mathrm{MSR}+1 / 2 \mathrm{RSSR}+\mathrm{L}+\mathrm{L}
$$


Table -1 : INFLUENCE OF Cu(II), Zn(II) AND Ni(II) COMPLEXES OF PHPO, CPHPO, MPHPO AND DMPHPO ON THE GROWTH OF VIRUS (VIGNA SINENSIS) ON COWPEA PLANT AT DIFFERENT CONCENTRATIONS.

\begin{tabular}{|c|c|c|c|c|c|c|c|c|c|c|c|c|c|}
\hline \multirow{2}{*}{ COMPLEX } & \multirow{2}{*}{ CONTROL } & \multicolumn{3}{|c|}{$1500 \mathrm{ppm}$} & \multicolumn{2}{|c|}{$1250 \mathrm{ppm}$} & \multicolumn{2}{|c|}{$1000 \mathrm{ppm}$} & \multicolumn{2}{|c|}{$750 \mathrm{ppm}$} & \multicolumn{2}{|c|}{$500 \mathrm{ppm}$} & \multirow{2}{*}{$\begin{array}{l}250 \mathrm{ppm} \\
\% \text { of in- } \\
\text { hibition }\end{array}$} \\
\hline & & $\begin{array}{l}\text { Treat- } \\
\text { ment }\end{array}$ & $\begin{array}{l}\% \text { of in- } \\
\text { hibition }\end{array}$ & $\begin{array}{l}\text { Treat- } \\
\text { ment }\end{array}$ & $\begin{array}{l}\% \text { of in- } \\
\text { hibition }\end{array}$ & $\begin{array}{l}\text { Treat- } \\
\text { ment }\end{array}$ & $\begin{array}{l}\% \text { of in- } \\
\text { hibition }\end{array}$ & $\begin{array}{l}\text { Treat- } \\
\text { ment }\end{array}$ & $\begin{array}{l}\% \text { of in } \\
\text { hibition }\end{array}$ & $\begin{array}{l}\text { - Treat- } \\
\text { ment }\end{array}$ & $\begin{array}{l}\text { \%of in- } \\
\text { hibition }\end{array}$ & $\begin{array}{l}\text { Treat- } \\
\text { ment }\end{array}$ & \\
\hline PHPO(ligand) & 116 & $54 \pm 1$ & 53.4 & $58 \pm 2$ & 50.0 & $61 \pm 1$ & 47.3 & $68 \pm 1$ & 41.4 & $71 \pm 2$ & 38.8 & $75 \pm 1$ & 35.3 \\
\hline $\mathrm{Cu}(\mathrm{PHPO})_{2}$ & 116 & $39 \pm 1$ & 66.4 & $41 \pm 1$ & 64.7 & $44 \pm 2$ & 62.0 & $48 \pm 2$ & 58.6 & $52 \pm 1$ & 55.2 & $58 \pm 1$ & 50.0 \\
\hline $\mathrm{Zn}(\mathrm{PHPO})_{2}$ & 116 & $44 \pm 1$ & 62.1 & $47 \pm 1$ & 59.5 & $49 \pm 1$ & 57.8 & $53 \pm 1$ & 54.4 & $59 \pm 1$ & 49.1 & $63 \pm 2$ & 45.7 \\
\hline $\mathrm{Ni}(\mathrm{PHPO})_{2}$ & 116 & $49 \pm 1$ & 57.8 & $51 \pm 1$ & 56.0 & $54 \pm 1$ & 53.4 & $57 \pm 1$ & 50.9 & $60 \pm 1$ & 48.3 & $64 \pm 1$ & 44.8 \\
\hline CPHPO(ligand) & 109 & $55 \pm 1$ & 49.5 & $59 \pm 2$ & 45.9 & $65 \pm 2$ & 40.4 & $69 \pm 1$ & 36.7 & $73 \pm 1$ & 33.0 & $76 \pm 2$ & 30.2 \\
\hline $\mathrm{Cu}(\mathrm{CPHPO})_{2}$ & 109 & $41 \pm 2$ & 62.4 & $44 \pm 2$ & 59.6 & $49 \pm 1$ & 55.0 & $53 \pm 1$ & 51.4 & $56 \pm 1$ & 48.6 & $62 \pm 1$ & 43.1 \\
\hline $\mathrm{Zn}(\mathrm{CPHPO})_{2}$ & 109 & $47 \pm 1$ & 56.9 & $52 \pm 1$ & 52.3 & $57 \pm 1$ & 47.7 & $60 \pm 1$ & 44.9 & $62 \pm 2$ & 43.1 & $65 \pm 2$ & 40.4 \\
\hline $\mathrm{Ni}(\mathrm{CPHPO})_{2}$ & 109 & $52 \pm 1$ & 52.3 & $56 \pm 1$ & 48.6 & $60 \pm 2$ & 44.9 & $63 \pm 2$ & 42.2 & $65 \pm 1$ & 40.4 & $70 \pm 1$ & 35.8 \\
\hline MPHPO(ligand) & 120 & $59 \pm 2$ & 50.8 & $64 \pm 2$ & 46.7 & $69 \pm 1$ & 42.2 & $75 \pm 2$ & 37.5 & $79 \pm 1$ & 34.2 & $83 \pm 1$ & 30.8 \\
\hline $\mathrm{Cu}(\mathrm{MPHPO})_{2}$ & 120 & $44 \pm 1$ & 63.3 & $48 \pm 1$ & 60.0 & $52 \pm 2$ & 56.7 & $53 \pm 1$ & 55.8 & $55 \pm 1$ & 54.2 & $61 \pm 1$ & 46.2 \\
\hline $\mathrm{Zn}(\mathrm{MPHPO})_{2}$ & 120 & $50 \pm 1$ & 58.3 & $55 \pm 1$ & 54.2 & $58 \pm 1$ & 51.7 & $60 \pm 2$ & 50.0 & $62 \pm 1$ & 48.3 & $67 \pm 1$ & 44.2 \\
\hline $\mathrm{Ni}(\mathrm{MPHPO})_{2}$ & 120 & $54 \pm 1$ & 55.0 & $60 \pm 2$ & 50.0 & $62 \pm 1$ & 48.3 & $64 \pm 1$ & 46.7 & $65 \pm 2$ & 45.8 & $69 \pm 1$ & 42.5 \\
\hline DMPHPO(ligand) & 90 & $42 \pm 2$ & 53.3 & $45 \pm 1$ & 50.0 & $47 \pm 1$ & 47.8 & $51 \pm 1$ & 43.3 & $54 \pm 1$ & 40.0 & $56 \pm 1$ & 37.8 \\
\hline $\mathrm{Cu}(\mathrm{DMPHPO})_{2}$ & 90 & $28 \pm 1$ & 68.9 & $30 \pm 1$ & 66.7 & $33 \pm 2$ & 63.3 & $36 \pm 1$ & 60.0 & $40 \pm 1$ & 55.6 & $43 \pm 1$ & 52.2 \\
\hline $\mathrm{Zn}(\mathrm{DMPHPO})_{2}$ & 90 & $30 \pm 1$ & 66.7 & $33 \pm 1$ & 63.3 & $35 \pm 1$ & 61.1 & $38 \pm 1$ & 57.8 & $43 \pm 1$ & 52.2 & $47 \pm 1$ & 47.8 \\
\hline $\mathrm{Ni}(\mathrm{DMPHPO})_{2}$ & 90 & $34 \pm 1$ & 62.2 & $36 \pm 2$ & 60.0 & $39 \pm 1$ & 56.7 & $41 \pm 1$ & 54.4 & $45 \pm 2$ & 50.0 & $49 \pm 1$ & 45.6 \\
\hline
\end{tabular}


which restricts the growth of the organisms.

b. The neutral complex first penetrate the cell and at the site of action may undergo dissociation in to corresponding $1: 1$ binary complexes as shown below

$$
2 \mathrm{ML}_{2} \leftrightarrow \mathrm{M}(\mathrm{L})+\mathrm{M}(\mathrm{L})+\mathrm{L}+\mathrm{L}
$$

and these coordinative unsaturated species becomes toxic entities by combining with and blocking the metal binding sites of the enzymes.

It is evident from the mechanisms mentioned above that the toxic activity of a complex will depend on the stability of the complex in solution. In our early work ${ }^{15-18}$ overall and stepwise formation constant values of $\mathrm{Cu}(\mathrm{II}), \mathrm{Ni}(\mathrm{II})$ and $\mathrm{Zn}$ (II) complexes of PHPO, CPHPO, MPHPO and DMPHPO was calculated i.e., DMPHPO $>$ PHPO $>$ MPHPO $>$ CPHPO for ligands and for metals it is $\mathrm{Cu}(\mathrm{II})>\mathrm{Zn}$ (II) $>\mathrm{Ni}$ (II). The antiviral activity of $\mathrm{Cu}(\mathrm{II}), \mathrm{Ni}$ (II) and $\mathrm{Zn}$ (II) complexes of PHPO, CPHPO, MPHPO and DMPHPO was also follows same trend like overall and stepwise formation constants, i.e., $\mathrm{Cu}(\mathrm{DMPHO})_{2}>\mathrm{Zn}(\mathrm{DMPHO})_{2}>\mathrm{Ni}(\mathrm{DMPHO})_{2}>\mathrm{Cu}(\mathrm{PHPO})_{2}>\mathrm{Zn}(\mathrm{PHPO})_{2}>$ $\mathrm{Ni}(\mathrm{PHPO})_{2}>\mathrm{Cu}(\mathrm{MPHPO})_{2}>\mathrm{Zn}(\mathrm{MPHPO})_{2}>\mathrm{Ni}(\mathrm{MPHPO})_{2}>\mathrm{Cu}(\mathrm{CPHPO})_{2}>\mathrm{Zn}(\mathrm{CPHPO})_{2}>$ $\mathrm{Ni}(\mathrm{CPHPO})_{2}($ Table -1$)$. Complexes with higher solution stability and greater lipid solubility are more toxic towards the virus and hence they inhibit the virus growth. The higher toxicity of complexes over the ligands can be ascribed due to the effect of metal ions on normal cell process.

Acknowledgement

The author thanks Dr. R. Seshadri Naidu, Director, Academic Staff college, S.V.University, Tirupathi and Dr. N.S.Reddi, Principal, JNV, East Godavari for their valuable suggestions.

\section{References}

1. Anjaneyulu Y and Prabhakar Rao P Proc. Indian. Nath. Sci. Acad., 1989, 55(3), 5631.

2. Holm R H, and O'Connor M .J, Prog. Inorg. Chem., 1971, 14, 241.

3. Lense F T, Glover C A, Markham E C, Virginia .J. Sci., 1942, 3, 14.

4. Palaniandavar M and Natarajan C, Aust. J. Chem., 1980, 33, 737.

5. Russel J and Clarke H, J.Am.Chem.Soc., 1939, 61, 3651.

6. Devitt P F, Timony A and Vickars M A, J.Org.Chem., 1961, 26. 4941.

7. Buu - Hoi N P and Xuong N D, J.Org.Chem., 1958, 23, 39.

8. Kushwaha S C, and Dinakar Lal J B, Ind. J. Chem., 1967, 5, 82.

9. Mistra S S, and Dinakar, J. Indian. Chem. Soc., 1972, 6, 49.

10. Mallikarjun K G and Seshadri Naidu R, Thermo Chimica Acta, 1992.

11. Mallikarjun K G, E-J.Chem, 2004, 01(02), 105.

12. Mallikarjun K G, J. Indian. Chem. Soc., Accepted for publication.

13. Srivastava R S, Inorg. Chem. Acta., 1981, 56, 265.

14. Gershan H, Stephen S G and David Onley contr. Boyce Thompson Inst. 1969,24, 163.

15. Mallikarjun K G and Seshadri Naidu R, Asian. J. Chem., 1992, 4(1), 135.

16. Mallikarjun K G, Asian. J. Chem., 2003, 15(3\&4), 1585.

17. Mallikarjun K G, J. Indian. Chem. Soc., 2004, 81, 503.

18. Mallikarjun K G, Proc. Nat. Acad. Sci., India, 2004, 74(a)(II), 107. 


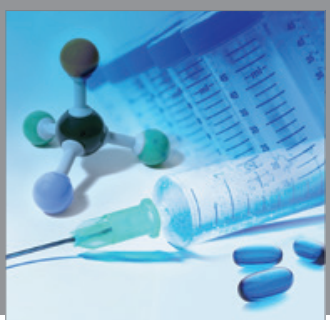

International Journal of

Medicinal Chemistry

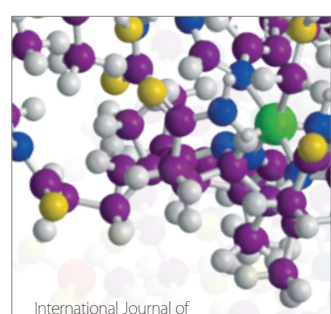

Carbohydrate Chemistry

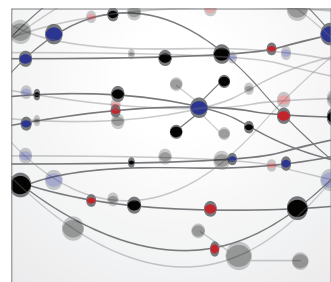

The Scientific World Journal
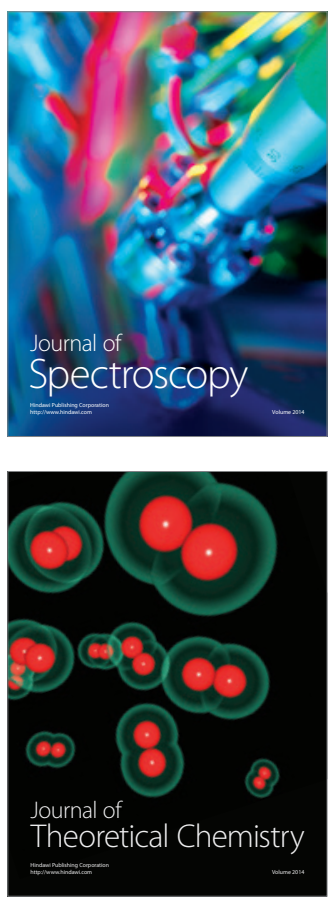
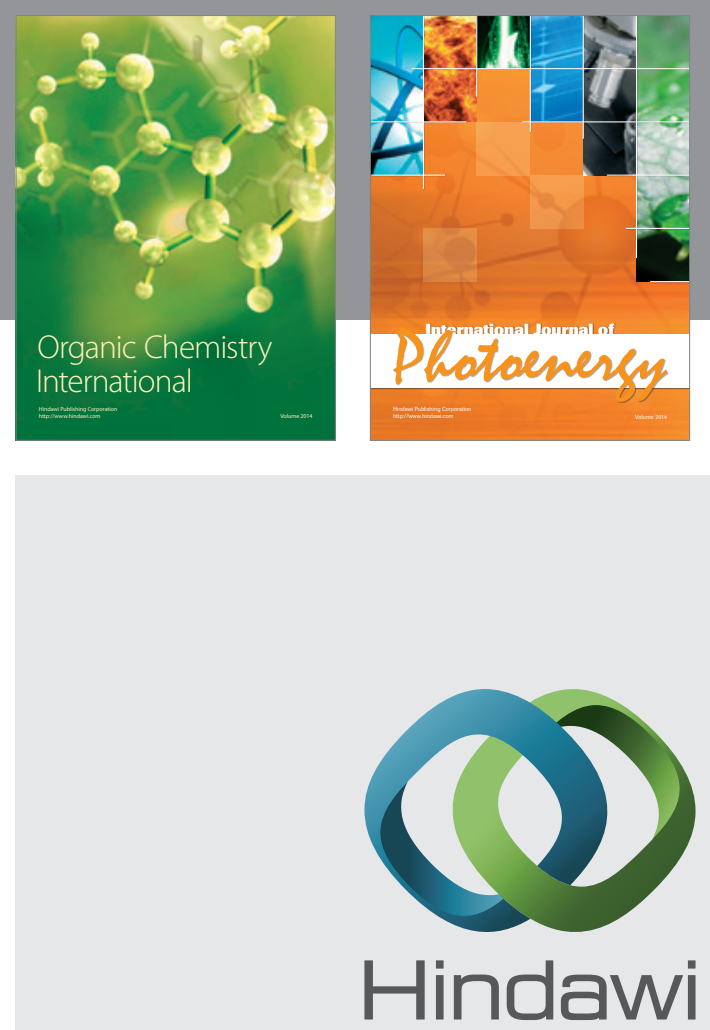

Submit your manuscripts at

http://www.hindawi.com
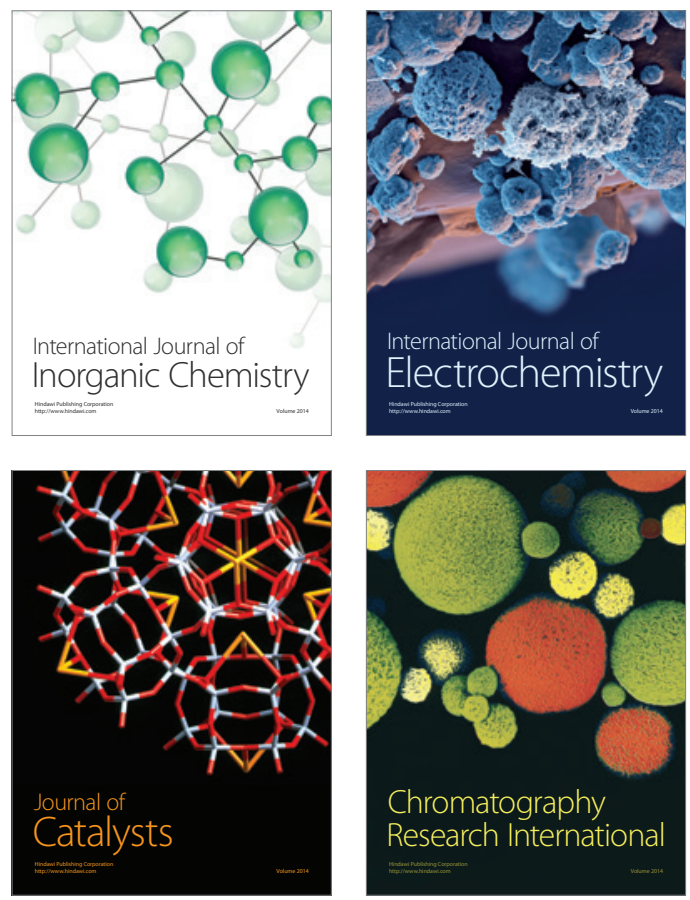
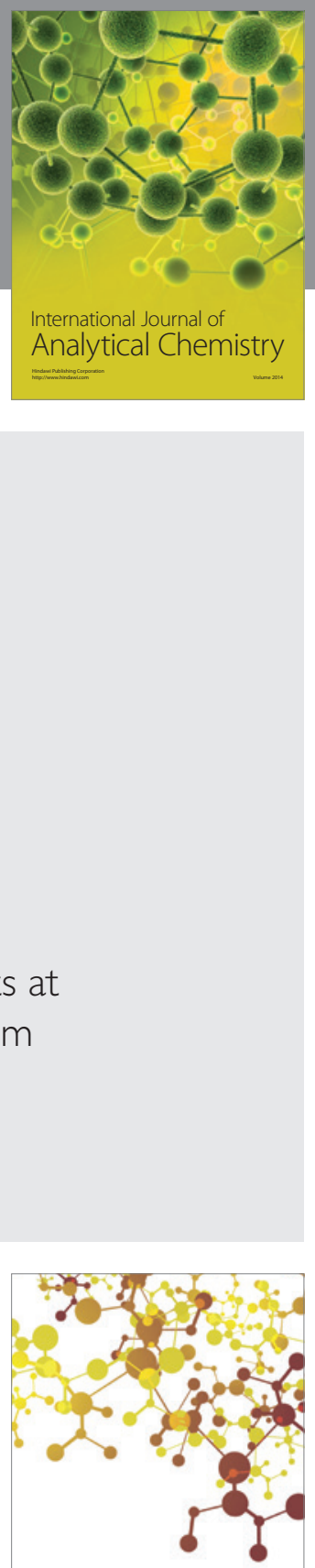

Journal of

Applied Chemistry
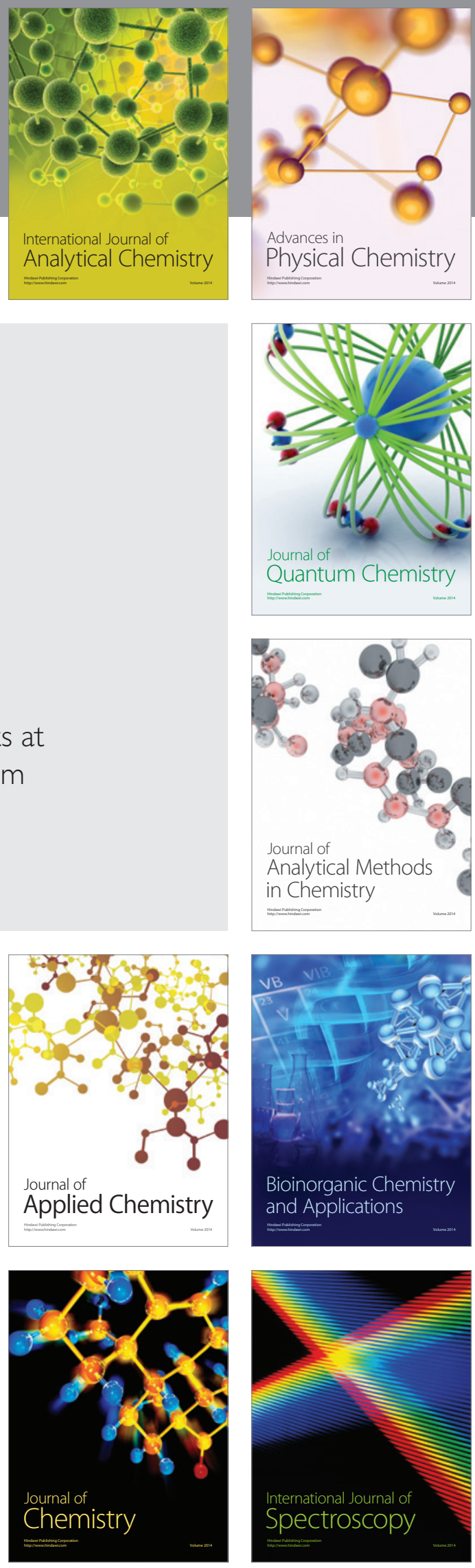